\title{
Gamma Radiation Effects Seed Germination, Plant Growth and Yield Attributing Characters of Fennel (Foeniculum vulgare Mill.)
}

\author{
Arvind Kumar Verma ${ }^{1}$, Sitaram Sharma ${ }^{2}$, Rajesh Kumar Kakani ${ }^{1}$, \\ Ram Dayal Meena ${ }^{1}$ and Sharda Choudhary ${ }^{1}$
}

\author{
${ }^{1}$ ICAR- National Research Centre on Seed Spices, Ajmer-305206, Rajasthan, India \\ ${ }^{2}$ Department of Horticulture, MJRP College of Agriculture, MJRP University, Jaipur - 302019, \\ Rajasthan, India \\ *Corresponding author
}

\begin{tabular}{|c|c|}
\hline & A B S T R A C T \\
\hline $\begin{array}{l}\text { Ke y w o r d s } \\
\text { Foeniculum } \\
\text { vulgare, Ionizing } \\
\text { radiation, Mutants, } \\
\text { Plant growth, } \\
\text { Seed germination }\end{array}$ & \multirow{3}{*}{$\begin{array}{l}\text { Narrow genetic base is the main problem hindering the conventional breeding in } \\
\text { fennel. Hence, an experiment was planned using the dried seeds of fennel } \\
\text { irradiated with different doses }(15 \mathrm{kR}, 17.5 \mathrm{kR}, 20 \mathrm{kR}, 22.5 \mathrm{kR} \text { and } 25 \mathrm{kR}) \text { of gamma } \\
\text { rays. The number of primary branches on harvesting was showed significant } \\
\text { difference as compared to control. In case of the number of secondary branches on } \\
\text { harvesting the difference was non-significant. The control plants showed earlier } \\
\text { ( } 87.6 \text { days) flowering compared to the gamma rays treated plants. In the same } \\
\text { way, earlier maturity was recorded in control ( } 143.6 \text { days) followed by } 15 \mathrm{kR} \\
\text { ( } 144.2 \text { days), } 17.5 \mathrm{kR} \text { ( } 145 \text { days), } 20 \mathrm{kR} \text { ( } 147 \text { days), } 22.5 \mathrm{kR} \text { (148.4 days) and } 25 \mathrm{kR} \\
\text { (150.4 days). Significant difference was observed with regards to number of } \\
\text { umbels per plant, number of umbellate per umbel, number of seeds per umbellate, } \\
\text { number of seeds per umbel, } 1000 \text { seed weight }(\mathrm{g}) \text { and seed yield per plant }(\mathrm{g}) \text {. }\end{array}$} \\
\hline Article Info & \\
\hline $\begin{array}{l}\text { Accepted: } \\
25 \text { April } 2017 \\
\text { Available Online: } \\
10 \text { May } 2017\end{array}$ & \\
\hline
\end{tabular}

\section{Introduction}

Fennel (Foeniculum vulgare Mill) is an annual, aromatic herb having yellow flowers and native of Southern Europe and Asia (Khan and Musharaf, 2014). It grows erect to a height of 2- $2.5 \mathrm{~m}$ and have hollow stem. The leaves of plant grow around $40 \mathrm{~cm}$ long and they are finely dissected with the ultimate segments filiform, about $0.5 \mathrm{~mm}$ wide. The flowers are arises in terminal compound umbels. The fruit is $4-10 \mathrm{~mm}$ long, dry seed, half as wide or less and groove. Mature fruit commonly known as seeds and have essential oil. It is also used as flavoring agents in food products such as liqueurs, bread, cheese and pharmaceutical and nutraceutical. Traditionally fennel is used as antispasmodic, diuretic, anti-inflammatory, analgesic, secretomotor, secretolytic, galactagogue, eye lotion and antioxidant cure (Lucinewton et al., 2005). Besides this, fennel infusions are the traditional decoction for treatment to prevent flatulence and colic spasms (MimicaDuki'c et al., 2003). In India, the total area under fennel is about 46760 ha, production 78570 tons and productivity is about $16.8 \mathrm{q} / \mathrm{h}$ (Spice Board India, 2015-16). It is cultivated throughout India at all altitudes up to 6,000 ft. Gujarat and Rajasthan are the main fennel 
growing states in India. It is grown in small scale in other states like Karnataka, Maharashtra, Uttar Pradesh, Punjab, Bihar, MP, Haryana and Jammu \& Kashmir. Although fennel cultivated worldwide, it requires a fairly mild climate and is cultivated as a cold weather crop in parts of North India. A dry and cold weather is conducive for better seed production. The potential yield of fennel is still low and there is an urgent need to increase the productivity. It is long duration crop and requires 6-7 months for maturity. Due to long duration crop farmers need to give more inputs to produce the crop. The normal plants height also high, hence, it creates the chances of lodging and ultimately it reduces the yield and quality of produce. The Ramularia blight and gummosis are another severe problems cause yield and quality loss (Malhotra, 2016).

The improvement of fennel crop was made mostly through conventional breeding method (selection). Low genetic variability, tiny flower size obstruct the artificial pollination and incompatibility due to protandrous, which promotes the cross pollination are the main drawback of conventional breeding methods in fennel (Bertin, 1993). Hence, for the improvement in any characters of the plants the most important requirement is to available variability in the gene pool. The variability may be available in natural population or it may be created by the methods of hybridization or mutation. Diminutive efforts have been made to improve fennel crop through genetic manipulation. Since, the variability naturally present in most of the seed spice crops including fennel is very low, so, induced mutation can be an option for improvement of this crop. Induced mutation has been widely used in a number of crops and species to generate broad spectrum of genetic variability. Mutation breeding is generally employed when low genetic variability present in a gene pool for particular trait (Fehr, 1993; Verma et al., 2017). Physical and chemical mutagens induce physiological damages, point mutations and chromosomal aberrations in $\mathrm{M}_{1}$ generation. Mutation induction with physical mutagens was the most frequently used method to develop mutant varieties (89\%). The use of chemical mutagens was relatively infrequent. Gamma rays were employed to developed $64 \%$ of the radiation induced mutant varieties, followed by $22 \%$ by X-rays (IAEA, 2015) gamma rays is an energetic form of electromagnetic radiations are recognized as the widely used mutagen for their simple application, good penetration, reproducibility and high mutation frequency (Chahal and Gosal, 2002) gamma rays having short wavelength with high penetrable power, interact with atoms or molecules to produce free radicals in the cells. Among the physical mutagens, gamma ray stands first in its effectiveness in the induction of mutation in crop plants (Jan et al., 2011; Verma et al., 2012).

Seed germination, plant survival, seedling growth, pollen sterility and chromosomal aberration are the normally used criteria for studying physical mutagens sensitivity in plants (Lal et al., 2009; Sangle et al., 2011). The usefulness of a mutagen in mutation breeding depends not only on its mutagenic effectiveness, but also on its mutagenic efficiency. The selection of effective and efficient mutagen(s) is very crucial to recover a high frequency and spectrum of desirable mutations in induced mutation (Solanki and Sharma, 1994). The mutagenic effectiveness decreased with the increase in dose of mutagen indicative of negative relationship between them (Ganapathy et al., 2008; Ramya et al., 2013). Mutations are mostly recessive and they cannot be selected until the second generation, whereas dominant mutations occur at very low frequencies and can be selected in the first generation. 
Although mutations are beneficial for producing variability in populations, the treatments themselves can be detrimental and can cause a reduction in germination, growth rate, plant viguor and pollen \& ovule fertility in a plant (Micke and Donini, 1993). Due to induced mutation, if we could get short stature and short duration plant with good yield, we can save the inputs required for producing crop, reduced the lodging problem, reduces the chances of crop damage by uncertain rain hailstorm etc. and farmers can take more crops on the same piece of land. The information generated will be useful for mutation breeding in fennel crop by using gamma ray.

\section{Materials and Methods}

The experiment was laid out at ICARNational Research Centre on Seed Spices, Ajmer, Rajasthan, during Rabi season of 2014-2015. The centre lies on $74035^{\prime} 39^{\prime \prime}$ to 740 36' 01 ' E longitude and 26022 ' 12 " to 26022 ' 31" N latitude at an altitude of 460.17 $\mathrm{m}$ above mean sea level. The climate of this zone is typically semi-arid and sub-tropical characterized by mild winter, moderate summers and associated with relatively high humidity during the month of JulySeptember. The mean annual rainfall is 590 $\mathrm{mm}$, mostly received from South-West monsoon during the last week of June to October. The dried seeds of fennel cv. RF-125 were used for irradiation. Seeds were exposed to different doses of gamma rays $(15 \mathrm{kR}$, $17.5 \mathrm{kR}, 20 \mathrm{kR}, 22.5 \mathrm{kR}$ and $25 \mathrm{kR}$ ) in gamma chamber containing $\mathrm{CO}^{60}$ as a source at Bhabha Atomic Research Centre (BARC), Mumbai. The dose rate of irradiation was 3.06 $\mathrm{K} \mathrm{kR} / \mathrm{h}$. The observation on seed germination, per cent survival number of leaves, total numbers of roots per, shoot length/plant height $(\mathrm{cm})$, fresh weight of the plant $(\mathrm{g})$, dry weight of the plant $(\mathrm{g})$, number of primary branches / plant, number of secondary branches / plant, days to flowering, days to maturity/harvesting, numbers of umbels / plant, numbers of umbellate / umbel, number of seeds / umbellate, number of seeds per umbel, test weight (g), seed yield / plant (g) were recorded. All the data were analyzed using the statistical software SPSS 16.0 (SPSS Inc., Chicago, IL, USA). The means were separated by Duncan Multiple Range Test (DMRT) at 5\% level of significance. The graphs were prepared by using Microsoft Office Excel.

\section{Results and Discussion}

\section{Effect of irradiation doses on seed germination, seedlings survival and plant growth}

The immediate effects of gamma rays treatments were recorded in terms of reduction in seed germination and seedling survival in $M_{1}$ generation. Perusal of data presented in Table 1 shows that the increase in dose of gamma rays, decreases the seed germination as well as survival of seedlings in fennel. Seed germination was $100 \%$ in control and among the different doses of gamma rays, the maximum seed germination was observed at lowest dose $15 \mathrm{kR}(72.67 \%)$ followed by $17.5 \mathrm{kR}(69.67 \%), 20 \mathrm{kR}(68.33 \%), 22.5 \mathrm{kR}$ $(66.00 \%)$ and $25 \mathrm{kR}(51.67 \%)$ which was statically significant differed from control. The observations of seedlings survival clearly showed that the increased doses of gamma rays having lethal effect on seedlings survival. The gamma rays dose of $25 \mathrm{kR}$ showed $51.67 \%$ seeds germination and $28.00 \%$ seedlings survival as compared to control, while 20kR recorded $68.33 \%$ seed germination and $49.33 \%$ survival of seedlings. Therefore, it is concluded that the optimum dose for germination and survival of fennel is $20 \mathrm{kR}$ and this dose statistically different from other doses with regards to reduction in seed germination and seedlings 
survival. The results indicated that the decreased in the seedling height in all doses of gamma rays may be due to increase in seedling injury. The gamma rays had a highly significant impact on reduction in number of leaves, number of roots, root length, shoot length and fresh weight per plant. The number of leaves per plant (15.4), number of roots (9), root length (6.66), shoot length $(6.24 \mathrm{~cm})$ and fresh weight per plant $(0.0491 \mathrm{~g})$ was recorded at the dose of $20 \mathrm{kR}$. The number of leaves per plant, number of roots per plant and root length was at par with $17.5 \mathrm{kR}$ dose of gamma rays. The growth parameters were dose dependent, as the dose of gamma rays increased from $15 \mathrm{kR}$ to $25 \mathrm{kR}$ there was gradual decrease in number of leaves, number of roots per plant, root length, shoots length and fresh weight per plant and increase in seedling injury were recorded. Among the different doses of gamma rays, the maximum number of leaves (20.8), number of roots per plant (17.2), root length $(16.94 \mathrm{~cm})$, shoots length $(12.86 \mathrm{~cm})$ and fresh weight per plant $(0.0904 \mathrm{~g})$ was observed at lowest dose of gamma rays $(15 \mathrm{kR})$ followed by $175 \mathrm{kR}$, $20 \mathrm{kR}, 22.5 \mathrm{kR}$ and $25 \mathrm{kR}$. It was recorded that about $50 \%$ seedling survivability and 50\% reduction in vegetative growth parameters at $20 \mathrm{kR}$ of gamma rays.

The results presented in Fig. 1 regarding to plant height at different growth stages. The growth of plants significantly reduced in gamma rays irradiated plants when compared the control. The shoot length in $15 \mathrm{kR}$ irradiated plants was $11.82 \mathrm{~cm}$ while in control plants were $14.66 \mathrm{~cm}$ and it reduced with the increase in the dose of gamma rays after 40 DAS. It indicates that the increase in dose of gamma rays increases the damage of seedlings. The height of plants significantly reduced in irradiated plants as compared to the control. The plants height at 60 DAS was $38 \mathrm{~cm}$ in control where as reduced to $36.2 \mathrm{~cm}$ in $15 \mathrm{kR}$ irradiated plants followed by $17.5 \mathrm{kR}$
$(34.1 \mathrm{~cm}), 20 \mathrm{kR}(32.4 \mathrm{~cm}), 22.5 \mathrm{kR}(31.8 \mathrm{~cm})$ and $25 \mathrm{kR}(29.8 \mathrm{~cm})$. The Plant height on harvesting was $140 \mathrm{~cm}$ in control followed by $15 \mathrm{kR}(136.4 \mathrm{~cm}), 17.5 \mathrm{kR}(133.2 \mathrm{~cm}), 20 \mathrm{kR}$ $(123.2 \mathrm{~cm}), 22.5 \mathrm{kR}(122.4 \mathrm{~cm})$ and $25 \mathrm{kR}$ $(121.4 \mathrm{~cm})$. Growth and development in crop did not proceed at constant or fixed rates through time. Gamma irradiation of seeds has been found to exert pronounced effects on plant growth.

The growth of plants affected by exposure with different doses of gamma rays, the result evident from Table 2 shows that the number of primary and secondary branches on 60 DAS reduced at $15 \mathrm{kR}(5.2), 17.5 \mathrm{kR}$ (6.2), $20 \mathrm{kR}(6), 22.5 \mathrm{kR}(6)$ as compared to control (6.4). The primary branches at gamma rays dose of $25 \mathrm{kR}$ were higher (6.8) but non significant as compared to control. The number of primary and secondary branches at harvesting time in some gamma rays dose was decreased and in some dose was increased as compared to control (Table 2). Gamma ray doses 15kR (9.4), 17.5kR (12.2), 20kR (13.8) and $22.5 \mathrm{kR}$ (14) reduced the numbers of primary branches as compared to control (14) at the time of harvesting The irradiation dose $25 \mathrm{kR}$ shown higher (15.4) and significant numbers of primary branches results. There was an increase in the numbers of secondary branches in all irradiated plants and maximum number of secondary branches was observed at $20 \mathrm{kR}$ (34) of gamma rays.

The relationship between dose of gamma rays and germination percentage in fennel was inversely proportional. As the dose of gamma rays was increased the germination and survival rate decreased. In a study the germination percentage and percent survival decreased with an increase in dose/concentration of the mutagens in fenugreek (Bashir et al., 2013). They concluded that lower treatments of mutagens have influenced less biological damage and 
would be suitable for inducing desirable mutations. Similar findings were reported where in higher doses of gamma radiation reduced germination percentage and survival in Moluccella laevis (Minisi et al., 2013). The reduction in germination and survival may be due to absorption of ionizing radiation in biological materials, acting directly on critical targets in the cell (Kovacs and Keresztes, 2002). Some of the seedlings were germinated but they died in further growth due to the injury caused by gamma rays. In this study, it was found that mutagenic treatment severely affected germinability in $\mathrm{M}_{1}$ generation confirming earlier mutation work done on fenugreek using chemical mutagens (Basu et al., 2008; Siddiqui et al., 2008). Higher doses ( $>5 \mathrm{kR}$ ) of gamma radiation had negative effects in nigella (Maamoun et al., 2014). However, the base populations differed in their response to mutagenic treatment confirming earlier work about use of multiple adapted cultivars for crop improvement using mutation breeding (Yadav and Krishna, 2013). Relationship between mutagenic dose and germination percentage was inversely proportional has been recorded in coriander (Mahla et al., 1999) and asshwagandha (Bhosale and More, 2014). These results were in accordance with the earlier report wherein, it was observed that the plantlet survival rate kept decreasing with increasing irradiation dosage for three weeks after irradiation in Centella asiatica (Moghaddam et al., 2011). The results obtained indicated that survival of plants to maturity depends on the nature and extent of chromosomal damage. Increasing frequency of chromosomal damage with increasing radiation dose may be responsible for less germinability and reduction in plant growth and survival (Kiong et al., 2008). The inhibition of seed germination at high doses could be due to the damage in seed tissue, chromosomes and subsequent mitotic retardation and the severity of the damage depend on the doses used (Datta, 2009).
With regards to plant growth, increased in gamma rays doses significantly decreased in pant growth parameters. The high dose irradiation that caused growth inhibition could be ascribed to the cell cycle arrest during somatic cell division and/or various damages in the entire genome (Preussa and Britta, 2003). In another report the higher efficiency of lower dose of gamma rays could be described to the fact that biological damage (seedling injury, lethality and sterility) increased with increase in dose at faster rate than the mutations. Inhibition effect by gamma-irradiation may be related to auxin and DNA biogenesis in a relationship which showed that auxin required for the formation of DNA and radiation block occurring in the formation of auxin and nucleic acid synthesis (Momiyama et al., 1999; Krasaechai and Yu, 2009). Growth and development in plants do not advance at invariable rates through time. Development of plant is a term that comprises a broad spectrum of processes by which plant structures originate and mature as growth occurs. Any change in growth pattern will ultimately affect maturity and yield. Gamma irradiation of seed has been found to exert pronounced effects on plant growth. The exposure to gamma irradiations can have stimulatory effects on some particular morphological characters and can enhance the yield of plants in terms of growth, reproductive and ability to withstand water shortage.

\section{Effect of irradiation on flowering and yields attributing characters}

A glance of result presented in Table 3 revealed that the gamma rays significantly affected the number of days required for flowering and maturity. The gamma rays dose delayed the flowering in irradiated plants than control plants (87.6 days). Among the irradiated plants, early flowering was observed on $15 \mathrm{kR}$ (88.6 days), followed by 
$17.5 \mathrm{kR}$ (89 days), 20kR (91.4 days), $22.5 \mathrm{kR}$ (92.8 days) and $25 \mathrm{kR}$ (93.8 days). Significant difference was observed in all doses of gamma rays except for $15 \mathrm{kR}$ with regards for delaying in flowering as compared to control. This observation revealed that higher dose of gamma rays has significant cause the delaying of flowering. The number of days required for maturity was increased with increase in the dose of gamma rays. The lowest gamma rays dose $15 \mathrm{kR}$ (144.2) took minimum days to maturity among all irradiated dose. The results with this regard revealed that the maturity of fennel crop delayed by application of gamma rays.

The data presented in Table 4 indicated that the application of gamma rays had significant effect on yield attributes related aspect as compared to non irradiated plants. The gamma irradiation doses have significant effect on number of umbel per plant. The number of umbel per plant was maximum on the dose of $25 \mathrm{kR}$ (31.8), followed by $20 \mathrm{kR}$ (30.8) and 17.5kR (29.6) and this results was significance when compared to control (24.4). The number of umbellate per umbel significantly decreased in all doses of gamma rays as compared to control. It can be infers that gamma rays had negative effect on number of umbellate per umbel. Nevertheless, the pre-sowing treatment of gamma rays resulted in increase the number of seeds per umbellate on all doses of gamma rays compared to control.

The maximum number of seeds per umbellate was recorded at the gamma rays doses of $25 \mathrm{kR}$ (34.8) followed by $22.5 \mathrm{kR}$ (30.2), 20kKR (29.8), 15kR (29.4) and $17.5 \mathrm{kR}$ (29.2). The maximum number of seeds per umbel was recorded on gamma rays dose of $22.5 \mathrm{kR}$ (866), followed by $25 \mathrm{kR}$ (863.6), $17.5 \mathrm{kR}$ (836) 20kR (834.4), 15kR (743) and control regarded the least (732.4). The 1000 seed weight was deceased in all irradiated plants with different doses as compared to control. The numbers of seeds per umbel were more but test weight was lower due to small seed formation in irradiated plants. The maximum seed weight was observed in control $(732.4 \mathrm{~g})$ followed by $20 \mathrm{kR}(6.24 \mathrm{~g})$, $25 \mathrm{kR}(5.32 \mathrm{~g}), 15 \mathrm{kR}(4.97 \mathrm{~g}), 17.5 \mathrm{kR}(4.76 \mathrm{~g})$, $25.5 \mathrm{kR}(4.67 \mathrm{~g})$. The seed yield was increased in the dose of $20 \mathrm{kR}(42.4 \mathrm{~g}), 25 \mathrm{kR}(41.6 \mathrm{~g})$ followed by $22.5 \mathrm{kR}(39 \mathrm{~g})$ and decreased in $175 \mathrm{kR}(32.4 \mathrm{~g})$ and $20 \mathrm{kR}(31 \mathrm{~g})$ as compared to control $(36.8 \mathrm{~g})$.

In induced mutation it was found that mutants showed early flowering in coriander (Datta and Sengupta, 2002). An experiment was conducted by exposing the seeds to gamma rays, ethyl methane sulphonate and sodium aside in fenugreek. The study revealed that pollen fertility decreased with an increase in dose/concentration of the mutagens (Bashir et al., 2016). Delayed in first flowering in ashwagandha was reported by the irradiated the seeds with different dose of gamma rays (Bharathi et al., 2013). Our result was also same as we also found delayed in flowering in gamma rays irradiated plants. Increasing concentration of both chemical mutagens led to gradual reductions in the number of days to flower by stimulating early initiation of flower bud. However, higher concentration of both chemical mutagens caused a delay in the number of days to flower in soybean (Mensah et al., 2013).

The increase in the quantitative and qualitative characters of the crop is one of the most important objectives of crop improvement. Any change in growth pattern was finally affected the maturity and yield. The exposure to gamma irradiations has stimulatory effects on specific morphological parameters and can increase the plants in terms of growth and yield. We found the increase in yield attributes character of fennel by the irradiation. 
Table.1 Effect of different doses of gamma irradiation on seed germination, seedlings survival and plant growth at 30 DAS. Same superscript letters in a column do not differ significantly when compared by DMRT test at $5 \%$ level of significance

\begin{tabular}{cccccccc}
\hline Dose (kR) & $\begin{array}{c}\text { Germination } \\
\text { percentage } \\
\text { (Relative) }\end{array}$ & $\begin{array}{c}\text { Survival } \\
\text { percentage }\end{array}$ & $\begin{array}{c}\text { Number } \\
\text { of leaves }\end{array}$ & $\begin{array}{c}\text { No. } \\
\text { of } \\
\text { roots }\end{array}$ & $\begin{array}{c}\text { Root } \\
\text { length } \\
(\mathbf{c m})\end{array}$ & $\begin{array}{c}\text { Shoot } \\
\text { length/plant } \\
\text { height }(\mathbf{c m})\end{array}$ & $\begin{array}{c}\text { Fresh } \\
\text { weight } \\
\text { per plant } \\
(\mathbf{g m})\end{array}$ \\
\hline $0($ Control $)$ & $100.00^{\mathrm{a}}$ & $100.00^{\mathrm{a}}$ & $20.8^{\mathrm{a}}$ & $17.2^{\mathrm{a}}$ & $16.94^{\mathrm{a}}$ & $12.86^{\mathrm{a}}$ & $0.0904^{\mathrm{a}}$ \\
15 & $72.67^{\mathrm{b}}$ & $67.33^{\mathrm{b}}$ & $17.2^{\mathrm{b}}$ & $12.2^{\mathrm{b}}$ & $9.02^{\mathrm{b}}$ & $8.76^{\mathrm{b}}$ & $0.0647^{\mathrm{b}}$ \\
17.5 & $69.67^{\mathrm{bc}}$ & $54.00^{\mathrm{c}}$ & $15.4^{\mathrm{c}}$ & $10.0^{\mathrm{c}}$ & $7.54^{\mathrm{c}}$ & $7.678^{\mathrm{c}}$ & $0.0633^{\mathrm{b}}$ \\
20 & $68.33^{\mathrm{c}}$ & $49.33^{\mathrm{d}}$ & $15.4^{\mathrm{c}}$ & $9.0^{\mathrm{c}}$ & $6.66^{\mathrm{c}}$ & $6.24^{\mathrm{d}}$ & $0.0491^{\mathrm{c}}$ \\
22.5 & $66.00^{\mathrm{c}}$ & $43.67^{\mathrm{e}}$ & $14.2^{\mathrm{c}}$ & $8.0^{\mathrm{de}}$ & $4.82^{\mathrm{d}}$ & $5.40^{\mathrm{e}}$ & $0.0439^{\mathrm{d}}$ \\
25 & $51.67^{\mathrm{d}}$ & $28.00^{\mathrm{f}}$ & $12.8^{\mathrm{d}}$ & $6.6^{\mathrm{e}}$ & $3.86^{\mathrm{d}}$ & $3.92^{\mathrm{f}}$ & $0.0260^{\mathrm{e}}$ \\
\hline
\end{tabular}

Table.2 Effect of different doses of gamma irradiation on number of primary branches per plant at 60 DAS and at harvesting and number of secondary branches per plant at harvesting. Same superscript letters in a column do not differ significantly when compared by DMRT test at 5\% level of significance

\begin{tabular}{cccc}
\hline Dose (kR) & $\begin{array}{c}\text { No. of primary } \\
\text { branches per plant } \\
\text { at 60 days }\end{array}$ & $\begin{array}{c}\text { No. of primary } \\
\text { branches per plant at } \\
\text { harvesting time }\end{array}$ & $\begin{array}{c}\text { No. of secondary } \\
\text { branches per plant at } \\
\text { harvesting time }\end{array}$ \\
\hline $0($ Control $)$ & $6.4^{\mathrm{a}}$ & $14^{\mathrm{ab}}$ & $31.0^{\mathrm{b}}$ \\
15 & $5.2^{\mathrm{b}}$ & $9.4^{\mathrm{d}}$ & $31.4^{\mathrm{b}}$ \\
17.5 & $6.2^{\mathrm{a}}$ & $12.2^{\mathrm{c}}$ & $32.8^{\mathrm{ab}}$ \\
20 & $6.0^{\mathrm{ab}}$ & $13.8^{\mathrm{b}}$ & $34.0^{\mathrm{a}}$ \\
22.5 & $6.0^{\mathrm{ab}}$ & $14.0^{\mathrm{ab}}$ & $33.0^{\mathrm{ab}}$ \\
25 & $6.8^{\mathrm{ab}}$ & $15.4^{\mathrm{a}}$ & $32.4^{\mathrm{ab}}$ \\
\hline
\end{tabular}

Table.3 Effect of different doses of gamma irradiation on number of days required for flowering and number of days required for maturity. Same superscript letters in a column do not differ significantly when compared by DMRT test at $5 \%$ level of significance

\begin{tabular}{ccc}
\hline Dose $(\mathbf{k R})$ & $\begin{array}{c}\text { Number of days required for } \\
\text { flowering }\end{array}$ & $\begin{array}{c}\text { Number of days required for } \\
\text { maturity }\end{array}$ \\
\hline $0($ Control $)$ & $87.6^{\mathrm{c}}$ & $143.6^{\mathrm{c}}$ \\
15 & $88.6^{\mathrm{c}}$ & $144.2^{\mathrm{c}}$ \\
17.5 & $89.0^{\mathrm{bc}}$ & $145.0^{\mathrm{bc}}$ \\
20 & $91.4^{\mathrm{abc}}$ & $147.0^{\mathrm{abc}}$ \\
22.5 & $92.8^{\mathrm{ab}}$ & $148.4^{\mathrm{ab}}$ \\
25 & $93.8^{\mathrm{a}}$ & $150.4^{\mathrm{a}}$ \\
\hline
\end{tabular}


Table.4 Effect of different doses of gamma irradiation on number of umbel per plant, number of umbellate per umbel, number of seeds per umbellate, number of seeds per umbel, 1000 seed weight, test weight and seed yield per plant. Same superscript letters in a column do not differ significantly when compared by DMRT test at $5 \%$ level of significance

\begin{tabular}{ccccccc}
\hline Dose (kR) & $\begin{array}{c}\text { Number of } \\
\text { umbel per } \\
\text { plant }\end{array}$ & $\begin{array}{c}\text { Number of } \\
\text { umbellate per } \\
\text { umbel }\end{array}$ & $\begin{array}{c}\text { Number of } \\
\text { seeds per } \\
\text { umbellate }\end{array}$ & $\begin{array}{c}\text { Number of } \\
\text { seeds per } \\
\text { umbel }\end{array}$ & $\begin{array}{c}\text { 1000 } \\
\text { seed } \\
\text { weight } \\
(\mathbf{g})\end{array}$ & $\begin{array}{c}\text { Seed } \\
\text { yield per } \\
\text { plant }(\mathbf{g})\end{array}$ \\
\hline $0($ Control $)$ & $24.4^{\mathrm{b}}$ & $29.2^{\mathrm{a}}$ & $29.2^{\mathrm{b}}$ & $732.4^{\mathrm{b}}$ & $6.33^{\mathrm{a}}$ & $36.8^{\mathrm{a}}$ \\
15 & $24.2^{\mathrm{b}}$ & $26.2^{\mathrm{b}}$ & $29.4^{\mathrm{b}}$ & $743.0^{\mathrm{b}}$ & $4.97^{\mathrm{c}}$ & $32.4^{\mathrm{c}}$ \\
17.5 & $29 .^{\mathrm{a}}$ & $23.4^{\mathrm{c}}$ & $29.2^{\mathrm{b}}$ & $836.0^{\mathrm{a}}$ & $4.76^{\mathrm{d}}$ & $31.0^{\mathrm{c}}$ \\
20 & $308^{\mathrm{a}}$ & $26.4^{\mathrm{ab}}$ & $29.8^{\mathrm{b}}$ & $834.4^{\mathrm{a}}$ & $6.24^{\mathrm{a}}$ & $42.4^{\mathrm{a}}$ \\
22.5 & $26.2^{\mathrm{b}}$ & $28.2^{\mathrm{ab}}$ & $30.2^{\mathrm{b}}$ & $866.0^{\mathrm{a}}$ & $4.67^{\mathrm{d}}$ & $39.6^{\mathrm{b}}$ \\
25 & $31.8^{\mathrm{a}}$ & $27.2^{\mathrm{ab}}$ & $34.8^{\mathrm{a}}$ & $863.6^{\mathrm{a}}$ & $5.32^{\mathrm{b}}$ & $41.0^{\mathrm{ab}}$ \\
\hline
\end{tabular}

Fig.1 Effect of different doses of gamma irradiation on plant growth

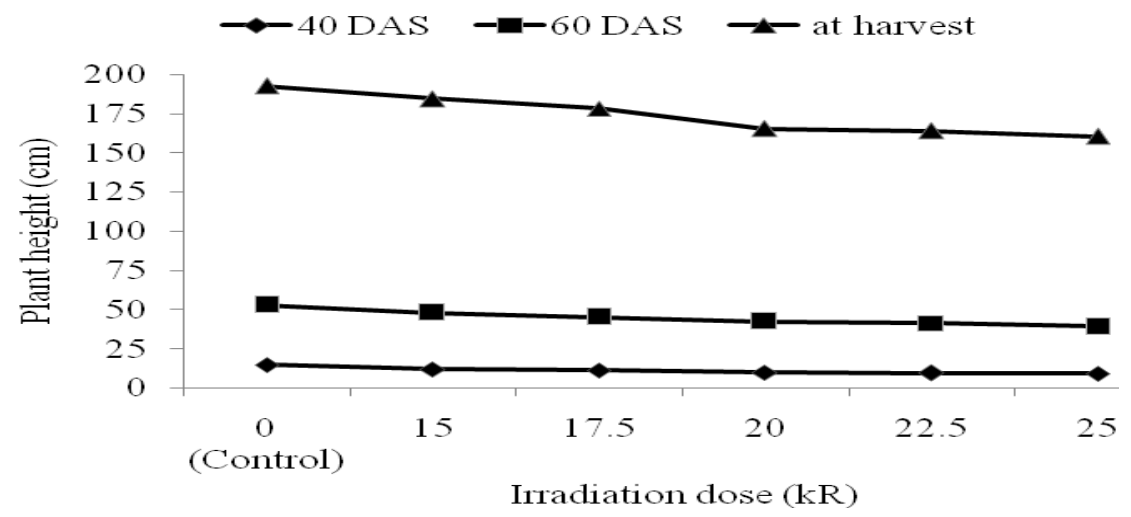

This result was supported by another experiment in which a very high magnitude of genetic coefficient of variability grain yield per plant followed by number of pods per plant and leaf area in black gram after gamma rays irradiation (Lal et al., 2009). A pot experiment conducted to study the effect of gamma-rays degraded sodium alginate on the performance of growth and yield of fennel. They observed that foliar spray of radiation degraded alginate improved the yield (umbels per plant, umbellets per umbel, hundred seed weight and seed yield) of fennel (Sarfaraz et al., 2011). By using different doses of gamma rays in fenugreek, two identified unique mutant which different from the parent line with respect to number of pods per plant and seed yield per plant (Kakani et al., 2012). In the same manner gamma rays induced variation in coriander (Singh et al., 1992). 15 viable types mutants selected in the $\mathrm{M}_{2}$ generation of celery, fennel and ajowan after treatments with gamma-rays and EMS. Gamma irradiation was more potent in inducing higher frequency of mutation than EMS in celery and ajowan (Paul and Datta, 2005). Nigella seeds expose to gamma rays increased the seed weight and seed number as compared to the control plants (Kumar and Gupta, 2007). 
Acknowledgement: The authors are thankful to the Director, NRCSS, Ajmer for provide necessary facility to carry out this experiment. We also thank Bhabha Atomic Research Centre, Mumbai for irradiation of seeds.

\section{References}

Bashir. S., Wani, A.A. and Nawchoo, I.A. 2013. Mutagenic sensitivity of gamma rays, EMS and sodium azide in Trigonella foenum-graecum L. Sci. Res. Reporter, 3: 20-26.

Basu, S.K., Acharya, S.N. and Thomas, J.E. 2008. Genetic improvement of fenugreek (Trigonella foenum-graecum L.) through EMS induced mutation breeding for higher seed yield under western Canada prairie conditions. Euphytica, 160: 249-258.

Bertin, R.I. 1993. Incidence of monoecy and dichogamy in relation to selffertilization in angiosperm. American $J$. Bot., 80: 557-560.

Bharathi, T., Gnanamurthy, S., Dhanavel, D., Murugan, S. and Ariraman, M. 2013. Induced Physical mutagenesis on seed germination, lethal dosage and morphological mutants of ashwagandha (Withania somnifera (L.) Dunal). Int. J. Adv. Res., 1: 136-141.

Bhosale, R.S. and More, A.D. 2014. Effect of gamma radiation on seed germination, seedling height and seedling injury in Withania somnifera, (L.) Dunal. Int. J. Life Sci., 2: 226-228.

Chahal, G.S. and Gosal, S.S. 2002. Principles and Procedures of Plant Breeding. Oxford: Alpha Science International Ltd. 399-412.

Datta, A.K. and Sengupta, K. 2002. Induced viable macromutants in coriander (Coriandrum sativum L.). Indian $J$. Genetics and Plant Breeding, 62: 273 274.

Datta, S.K. 2009. A report on 36 years of practical work on crop improvement through induce mutagenesis. In: induced plant mutations in the genomics Fra, Shu, Q.Y. (Fd). Food and Agriculture Organization of the United Nations, Rome, 253-256.

Fehr, W.R. 1993. Principles of Cultivar Development: Theory and Technique. Vol. II. Macmillan Publishing Company, USA.

Ganapathy, S., Nirmalakumari, A., Senthil, N., Souframanien, J. and Raveendran, T.S. 2008. Isolation of macromutations and mutagenic effectiveness and efficiency in little millet varieties. World J. Agri. Sci., 4: 483-486.

International Atomic Energy Agency (IAEA) 2015. Mutant variety database. https://mvd.iaea.org

Jan, S., Parween, T. and Siddiqi, T.O. 2011. Mahmooduzzafar. Effect of gamma radiation on morphological, biochemical, and physiological aspects of plants and plant products. Environ. Reviews, 20: 17-39.

Kakani, R.K., Saxena, S.N., Meena, S.S., Sharma, Y.K., Meena, R.S. and Kant, K. 2012. Two unique induced mutants identified in fenugreek for growth habit and leaf characteristics. Int. J. Seed Spices, 2: 66-68.

Khan, M. and Musharaf, S. 2014. Foeniculum vulgare Mill. A Medicinal Herb. Medicinal Plant Res., 4: 46-54.

Kiong, A., Ling Pick, A., Grace Lai, S.H. and Harun, A.R. 2008. Physiological responses of Orthosiphon stamineusplantlets to gamma irradiation. American-Eurasian J. Sustainable Agri., 2: 135-149.

Kovacs, E. and Keresztes, A. 2002. Effect of gamma and UV-B/C radiation on plant cell. Micron, 33: 199-210.

Krasaechai, A. and Yu, L.D. 2009. Lowenergy ion beam modification of horticultural plants for induction of 
mutation. Surface and Coatings Technol., 203: 2525-2530.

Kumar, G. and Gupta, P. 2007. Mutagenic efficiency of lower doses of gamma rays in black cumin (Nigella sativa L.). Cytologia, 72: 435-440.

Lal, G.M., Tums, B. and Lal, S.S. 2009. Mutagenic sensitivity in early generation in black gram. Asian $J$. Agric. Sci., 1: 9-11.

Lucinewton, S., Raul, N., Carvalho, J., Mirian, B., Lin, C. and Angela, A. 2005. Supercritical fluid extraction from fennel (Foeniculum vulgare), global yield, composition and kinetic data. $J$. Supercritical Fluids, 35: 212-219.

Maamoun, M.K.M., El-Mahrouk, M.E., Dewir, Y.H. and Omran, S.A. 2014. Effect of radiation and chemical mutagens on seeds germination of black cumin (Nigella sativa L.). J. Agri. Technol., 10: 1183-1199.

Mahla, H.R., Ramkrishna, K. and Sharma, R.K. 1999. An assessment of induced variability in $\mathrm{M}_{2}$ progenies of coriander. Annals of Arid Zone, 38: 81-83.

Malhotra, S.K. 2016. Recent advances in seed spices research - A review. Annals of Plant and Soil Res., 18: 300-308.

Mensah, J.K., Okooboh, G.O. and Osagie, I.P. 2013. Mutagenic effects of hydroxylamine and hydroquinone on some agronomic and yield characters of soybean (Glycine max L. Merr.). Int. J. Modern Botany, 3: 20-24.

Micke, A. and Donini, B. 1993. Induced mutations. In: Hayward MD, Bosemark NO, Ramagosa I (eds). Plant breedingprinciples and prospects. Chapman and Hall, London, 53-62.

Mimica-Duki'c, N., Kujund'zi'c, S., Sokovi'c, M. and Couladis, M. 2003. Indigenous populations of Foeniculum vulgare var. vulgare in Israel." Bioch. Systematic Ecol., 30:721-731.

Minisi, F.A., El-mahrouk, M.E., Rida, M.E.F. and Nasr, M.N. 2013. Effects of gamma radiation on germination, growth characteristics and morphological variations of Moluccella laevis $\mathrm{L}$. American-Eurasian J. Agri. Environ. Sci., 13: 696-704.

Moghaddam, S.S., Jaafar, H., Ibrahim, R., Rahmat, A. and Aziz, M.A. 2011. Philip E. Effects of acute gamma irradiation on physiological traits and flavonoid accumulation of Centella asiatica. Molecules, 16:4994-5007.

Momiyama, M., Koshiba, T., Furukawa, K., Kamiya, Y. and Satô. M. 1999. Effects of gamma irradiation on elongation and indole-3-acetic acid level of maize (Zea mays) coleoptiles. Environ. Experimental Botany, 41: 131-143.

Paul, R., Datta, A.K. 2005. Gamma-rays and EMS induced macromutants in celery (Apium graveolens L.), fennel (Foeniculum vulgare Mill.) and ajwain (Trachyospermum amni L.). J. Phytol. Res., 18: 95-98.

Preussa, S.B. and Britta, A.B. 2003. A DNAdamage induced cell cycle checkpoint in Arabidopsis. Genetics, 164: 323-334.

Ramya, B., Nallathambi, G. and Ram, S.G. 2013. Mutagenic effectiveness and efficiency of gamma rays and EMS in black gram (V. mungo L.). Int. $J$. Scientific Res., 2: 6-9.

Sangle, S.M., Mahamune, S.E., Kharat, S.N. and Kothekar, V.S. 2011. Effect of mutagenisis on germination and pollen steritity in pigeonpea. Biosci. Discovery, 2: 127-130.

Sarfaraz, A., Naeem, M., Nasir, S., Idrees, M., Atab, T., Hashmi. N., Khan, M.M.A., Moinuddin and Varshney, L. 2011. An evaluation of the effects of irradiated sodium alginate on the growth, physiological activity and essential oil production of fennel (Foeniculum vulgare Mill. J. Medicinal Plants Res., 5: 15-21. 
Siddiqui, S., Meghvansi, M.K., Khan, S.S. and Aali. N.S. 2008. Mutagenic effect of herbicide (Maleic hydrazide) on seed germination and radical length on Trigonella foenum-graecum L. Indian J. Appl. Pure Biol., 23:103-106.

Singh, B., Dashora, S.L., Sharma, R.K. and Sastry, E.V.D. 1992. Gamma rays induced variation in Coriandrum sativum L. Indian, Cocoa-Arecanut Spices J., 16: 60-62.

Solanki, I.S. and Sharma, B. 1994. Mutagenic effectiveness and efficiency of gamma rays, ethalemine and $\mathrm{N}$-nitroso-N-ethyl urea in macrosperma lentil (Lens culinaris Medik.). Indian J. Genetics and Plant Breeding, 54: 72-76.

Spice Board India database. 2015-16. http://indianspices.com

Verma, A.K., Kakani, R.K., Solanki, R.K. and Meena, R.D. 2017. Improvement in yield attributing traits of cumin (Cuminum cyminum) through acute exposure of gamma ray" Int. J. Pure \& Appl. Biosci., "in press".

Verma, A.K., Prasad, K.V., Singh, S.K. and Kumar, S. 2012. In vitro isolation of red coloured mutant from chimeric ray florets of chrysanthemum induced by gamma-ray. Indian J. Horticulture, 69: 562-567.

Yadav, S.K. and Krishna, K.R. 2013. Effectiveness and efficiency of physical and chemical mutagens on cumin (Cuminum cyminum L.). Vegeto, 26: 44-49.

\section{How to cite this article:}

Arvind Kumar Verma, Sitaram Sharma, Rajesh Kumar Kakani, Ram Dayal Meena and Sharda Choudhary. 2017. Gamma Radiation Effects Seed Germination, Plant Growth and Yield Attributing Characters of Fennel (Foeniculum vulgare Mill.). Int.J.Curr.Microbiol.App.Sci. 6(5): 2448-2458. doi: https://doi.org/10.20546/ijcmas.2017.605.274 